\title{
Assessment of adhesively bonded joints of aluminum sheets for application as the core of composite beams
}

\author{
Anna Derlatka ${ }^{1}$
}

\begin{abstract}
:
The paper presents an evaluation of joints resulting from adhesively bonded aluminum sheets. The aim of the study was to assess the possibility of applying this type of connection for the construction of composite beams. The results of experimental tests on the shear test of joints are presented. Four types of connectors were the subjects of the research. The joints of the same geometry were made of four $1.6 \mathrm{~mm}$ thick sheets of aluminum alloy AA 7075-T6. Each type of joint was characterized by a different material joining the sheets: three of them were connected by acrylic foam tapes, one joint was made using two component toughened methacrylate adhesive. Three different double-sided acrylic foam tapes with different properties were tested. It has been assessed that the two-component toughened methacrylate adhesive can be used for the construction of the aluminum core applied in composite structures.
\end{abstract}

\section{KEYWORDS:}

aluminium alloy; adhesively bonded joints; composite structures

\section{Introduction}

Aluminum alloys are a material that is increasingly used in modern construction. The works [1-4] mainly appreciate the lightness and durability of aluminum structures. Aluminum is approximately $65 \%$ lighter than steel. Aluminum alloys combine lightness with high tensile strength. Additionally, aluminum is non-toxic and can be easily processed, both by machining, plastic working, as well as by casting [5]. As emphasized in [6], the corrosion resistance of aluminum alloys reduces the maintenance costs of aluminum structures by eliminating the need for systematic application of anti-corrosion coatings. The disadvantage of products made of high strength aluminum alloys is the difficulty in joining them. The methods for joining products made of high-strength aluminum alloys are Friction Stir Welding (FSW) and Refill Friction Stir Spot Welding (RFSSW) as presented in [7-9].

Currently, composite materials such as carbon fibres are immensely popular, however, they are still considered expensive. Therefore, research is being carried out to develop new products by improving existing solutions. One of these types of materials are composites based on metal alloys, which, due to several properties, find numerous innovative applications presented in [10]. Their advantage is the low weight of products made from them, while meeting the required mechanical properties, and therefore operational safety, and maintaining a relatively low price.

Current scientific research focuses on the design of structures created by RFSSW welding. The articles [11-13] present solutions for complex composite structures. The load-bearing core of the tested beams were structures made of sheets. In all analysed composite structures,

1 Czestochowa University of Technology, Faculty of Civil Engineering, ul. Akademicka 3, 42-218 Częstochowa, e-mail: anna.derlatka@pcz.pl, orcid id: 0000-0002-6509-2706 
the sheets were made of two channels resulting from cold bending of the sheets made of AA 6061-T6 aluminum alloy. The thickness of the sheets was $0.8 \mathrm{~mm}$. The channels were joined along the webs with openings using RFSSW welding, resulting in an I-beam cross-section. Due to the buckling occurrence in the I-beam [11], it was necessary to stiffen the web. Polyurethane foam as well as polyurethane foam with glass fibres have been proposed for filling thin-walled structures. As a result, lightweight structures with high stiffness and high bending strength were obtained in $[12,13]$.

Both FSW and RFSSW require financial resources for the equipment and its depreciation. Therefore, cheaper methods for joining products made of high strength aluminum alloys are constantly being sought. One of them is adhesively bonding, which is popular in transport industry $[14,15]$.

Hence, the results of shear tests of such type connections are the subject of interest to researchers. In paper [16], a study of gap (recessing) length on the stress distribution in adhesively bonded aluminum double-lap joints was carried out. Results obtained in [17] shown that epoxy adhesive with metal filler addition gives a stronger strength of adhesion between aluminum sheets than adhesive itself. Hybrid joints consisted of aluminum plates, the polyurethane adhesive, reinforced by rivets are popular in aerospace structures [18]. However, the authors of works [19-21] emphasize that the method of surface preparation (mechanical, chemical, combined) of the connected sheets before bonding application affects the mechanical properties of the joint. In addition, the process of modifying the surface of aluminum sheets by applying the adhesive may contribute to corrosion of the joint [22] and a humid environment may influence fatigue cracks [23].

\section{Goal and scope of work}

The aim of the study was to assess the possibility of applying adhesive joints of aluminum sheets used in the construction of composite beams. The scope of the work includes an experimental analysis of sheet metal joints. A static shear test of joints was carried out, on the basis of which the mechanical properties of joints were assessed. The testing speed was of $2 \mathrm{~mm} / \mathrm{min}$.

The subject of the research were four types of joints, with geometries shown in Figures 1-3. Each joint was made of four $1.6 \mathrm{~mm}$ thick sheets of aluminum alloy AA 7075-T6. Each type of joint was characterized by a different commercial material connecting the sheets:

- Joint 1: type 1 of acrylic foam tape

- Joint 2: type 2 of acrylic foam tape

- Joint 3: type 3 of acrylic foam tape

- Joint 4: two-component adhesive

The foam tapes types $1-3$ are double-sided acrylic foam tapes intended for gluing various materials, including metals, plastics, varnished elements. Properties of the acrylic foam tapes used in tests are presented in Table 1 on the basis of specifications.

Table 1

Properties of commercial acrylic foam tapes

\begin{tabular}{|l|l|l|l|}
\hline Tape No. & Adhesive type & Foam density $\left[\mathrm{kg} / \mathrm{m}^{3}\right]$ & Foam thickness $[\mathrm{mm}]$ \\
\hline 1 & Modified Acrylic & 690 & 0.4 \\
\hline 2 & Acrylic & 590 & 0.6 \\
\hline 3 & Acrylic universal & 720 & 0.6 \\
\hline
\end{tabular}

The material used for joint 4 is a two component toughened methacrylate adhesive system. It can be used for joining various metal materials such as steel, stainless steel, aluminum, as well as for joining plastics and composites, such as CFRP or GFRP.

In accordance with the recommendations of the tape and adhesive glue manufacturers, for maximum bond strength the sheets surfaces were cleaned, degreased and dried before 
connecting. The application of tapes and glue was done manually. Three identical samples were made for each type of connection. The photos of exemplary adhesively bonded connectors are shown in Figure 4.

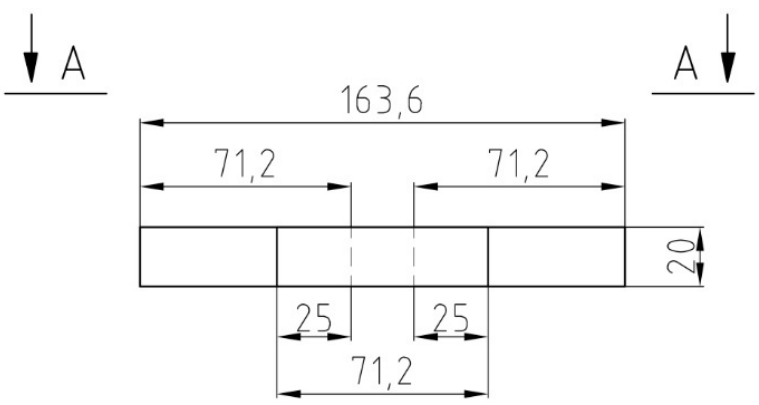

Fig. 1. Geometry of joints $1-4$, top view

a)

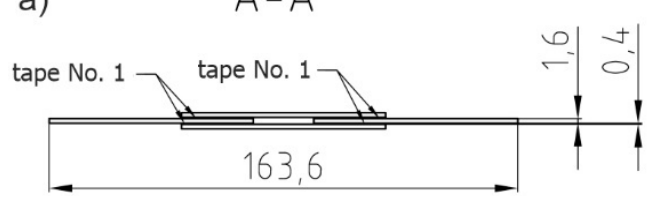

b) $\quad A-A$

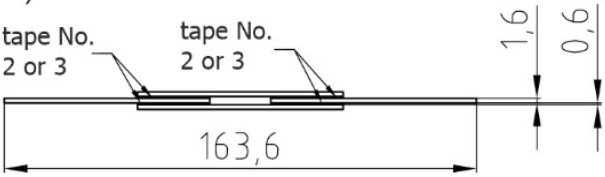

Fig. 2. Geometry of joints (A-A side view): a) joint 1, b) joints 2, 3

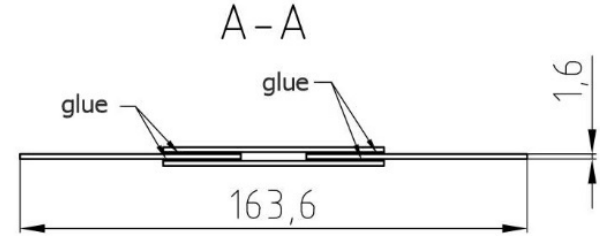

Fig. 3. Geometry of joint 4 (A-A side view)

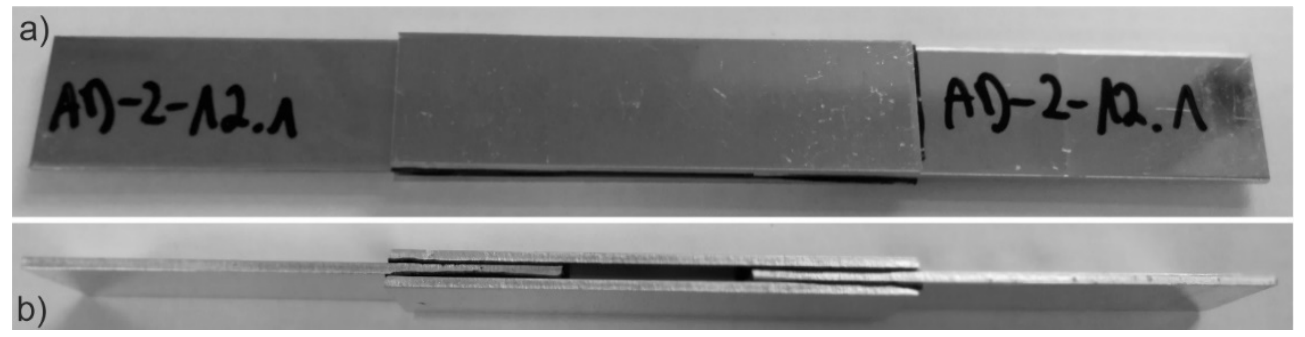

Fig. 4. Photos of exemplary joint: a) top view, b) side view

\section{Results}

Diagrams of displacement - load from the shear tests are presented in Figure 5. Due to the exceptionally large differences in load-bearing capacities between the connections, a different scale was used in the diagrams. The maximum forces carried by all samples are shown in Table 2 .

Joint 1 (tape adhesion) carried an average shear force of $0.217 \mathrm{kN}$. The standard deviation is $0.0014 \mathrm{kN}$. Joint 2 transferred the average shear force of $0.249 \mathrm{kN}$. The standard deviation is $0.0025 \mathrm{kN}$. Joint 3 carried the average shear force of $0.197 \mathrm{kN}$. The standard deviation is $0.0124 \mathrm{kN}$. 


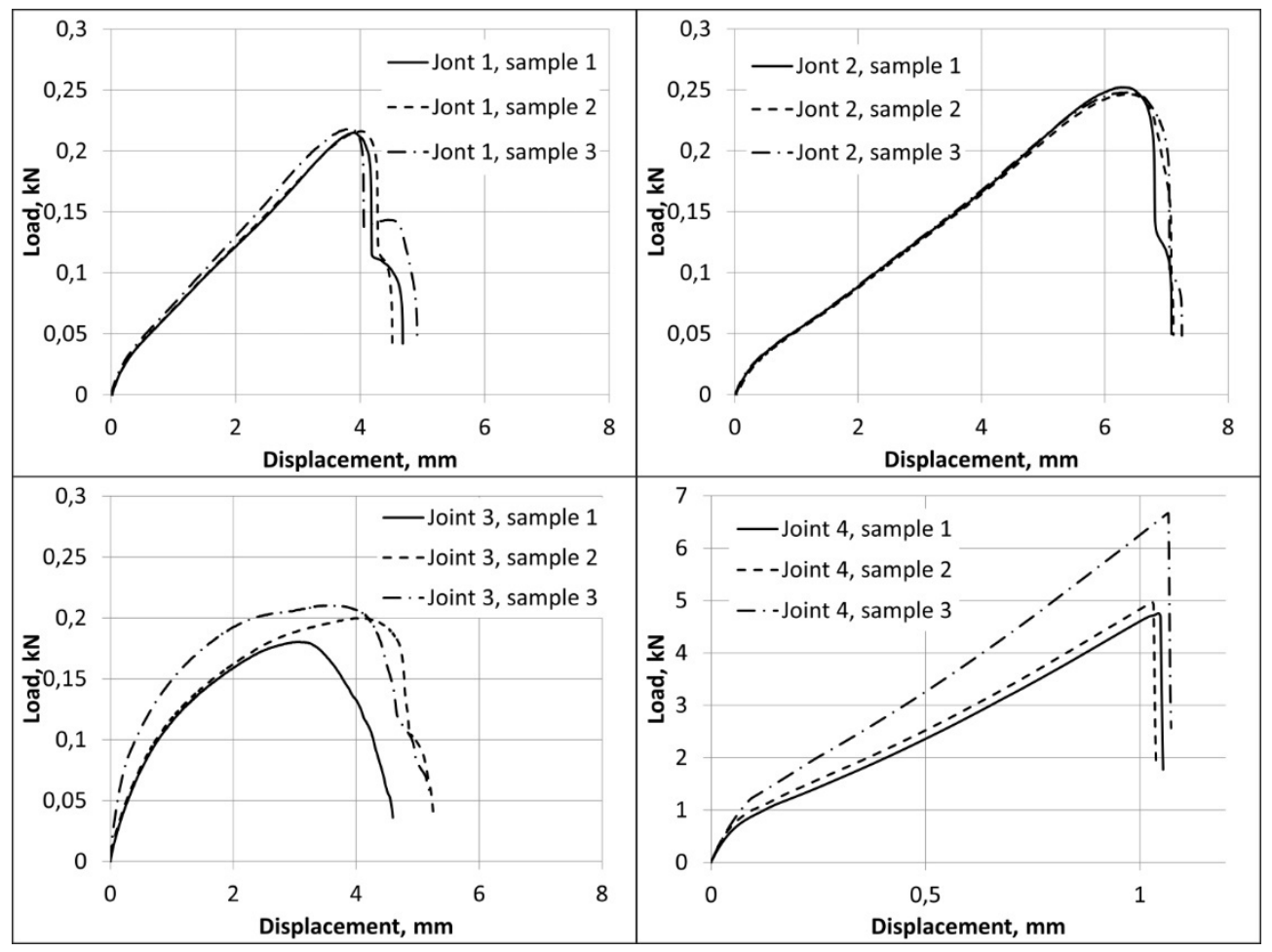

Fig. 5. Displacement - load plots for joints $1-4$ (different limits was used in diagrams because the exceptionally large differences in load-bearing capacities between the connections)

Table 2

Summary of results for analysed joints

\begin{tabular}{|c|c|c|c|c|c|}
\hline Joint & Sample & $\begin{array}{l}\text { Maximum load } \\
{[\mathrm{kN}]}\end{array}$ & $\begin{array}{l}\text { Average load } \\
{[\mathrm{kN}]}\end{array}$ & $\begin{array}{l}\text { Standard deviation } \\
{[\mathrm{kN}]}\end{array}$ & $\begin{array}{l}\text { Displacement corresponding } \\
\text { to maximum force }[\mathrm{mm}]\end{array}$ \\
\hline \multirow{3}{*}{$\begin{array}{l}\text { Joint } 1 \\
\text { (tape) }\end{array}$} & 1 & 0.215 & \multirow{3}{*}{0.216} & \multirow{3}{*}{0.0014} & 3.888 \\
\hline & 2 & 0.216 & & & 4.026 \\
\hline & 3 & 0.219 & & & 3.834 \\
\hline \multirow{3}{*}{$\begin{array}{l}\text { Joint } 2 \\
\text { (tape) }\end{array}$} & 1 & 0.252 & \multirow{3}{*}{0.249} & \multirow{3}{*}{0.0025} & 6.257 \\
\hline & 2 & 0.246 & & & 6.345 \\
\hline & 3 & 0.248 & & & 6.377 \\
\hline \multirow{3}{*}{$\begin{array}{l}\text { Joint } 3 \\
\text { (tape) }\end{array}$} & 1 & 0.180 & \multirow{3}{*}{0.197} & \multirow{3}{*}{0.0124} & 3.085 \\
\hline & 2 & 0.200 & & & 4.062 \\
\hline & 3 & 0.210 & & & 3.595 \\
\hline \multirow{3}{*}{$\begin{array}{l}\text { Joint } 4 \\
\text { (glue) }\end{array}$} & 1 & 4.756 & \multirow{3}{*}{5.500} & \multirow{3}{*}{0.8565} & 1.044 \\
\hline & 2 & 4.970 & & & 1.029 \\
\hline & 3 & 6.670 & & & 1.066 \\
\hline
\end{tabular}

Joint 4 (adhesion by glue) transferred the average shear force of $5.5 \mathrm{kN}$. The standard deviation is $0.8565 \mathrm{kN}$. Repeatability of the results in samples 1 and 2 was observed. The shear force transferred by sample 3 is $30 \%$ greater than the forces transferred by the others. 
The displacements corresponding to the maximum forces of the joints are shown in Table 2 . The displacement of the joints no $1-3$ is the range of $3.085 \div 6.377 \mathrm{~mm}$. However, the displacement of joint 4 is about $1.0 \mathrm{~mm}$.

All joints were damaged as a result of shearing the connector (tape or glue) and separating the connected components from each other, as presented in Figure 6.

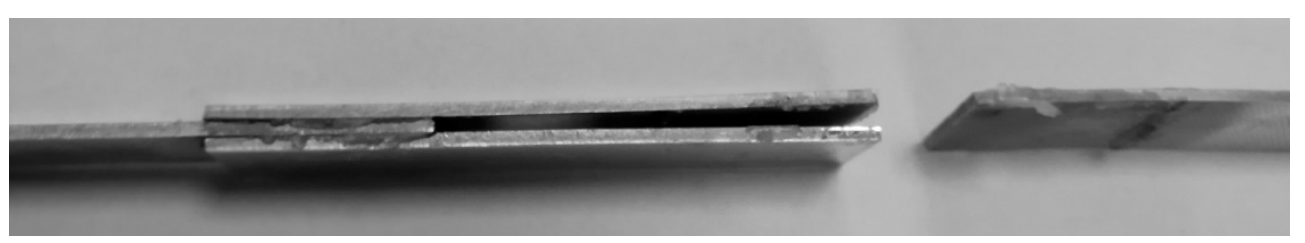

Fig. 6. Joint 4 after shear test

\section{Discussion}

The list of the shear resistance of the joints is presented in box plots. As shown in Figure 7, small boxes of the joints made with the use of tapes prove the high repeatability of the results. The shear resistance of all joints with the tape is similar, which proves that it does not depend on the tape thickness.

Comparing the shear capacity of all analysed joints marked $1-4$, the greatest forces were carried by joint 4 created with the use of glue. Considering joint 4 , the difference of the shear force carried by sample 3 to the forces carried by samples 1 and 2 results from the manual application of the adhesive glue and from insufficient experience in applying this type of connector.

Based on the displacement values it was concluded that the joints marked $1-3$ (bonded by tapes) are ductile connections. On the other hand, the displacement of joint 4 shows that the glued joint is characterized by brittle failure.

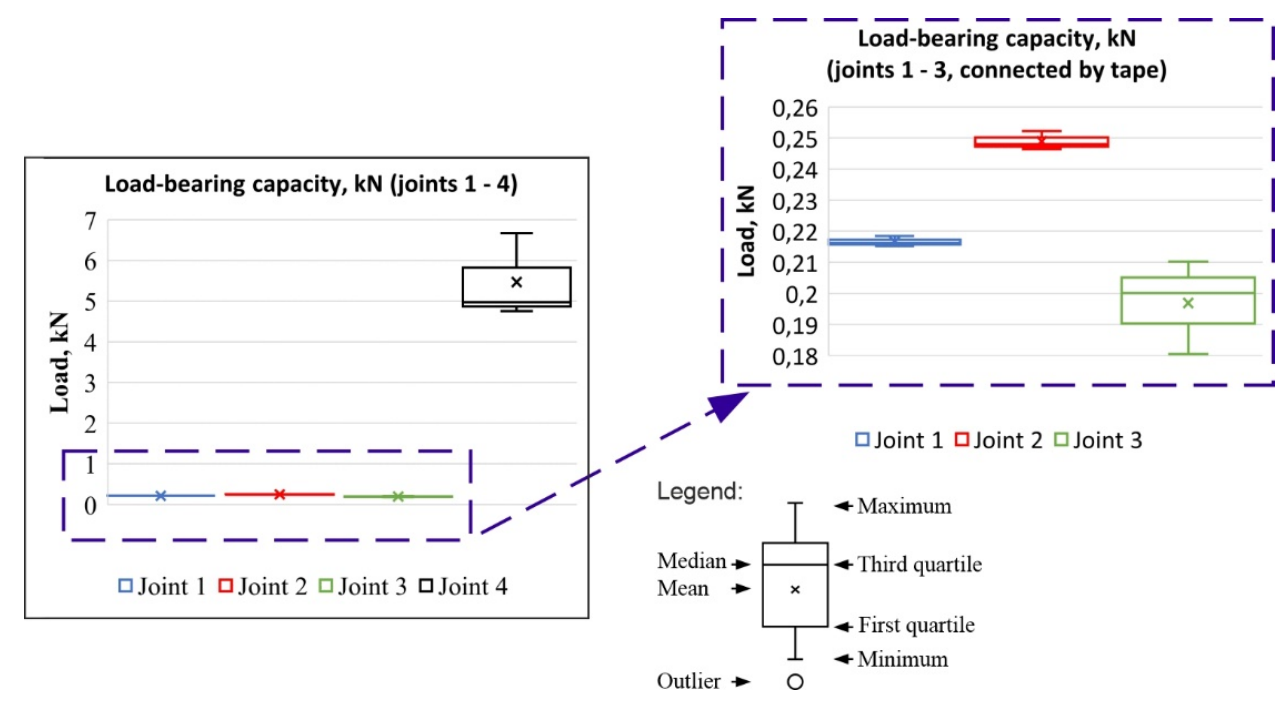

Fig. 7. Summary of results for analyzed joints

\section{Conclusions}

- Among all the analysed joints, the highest shear loads were achieved by joints made with the two-component methacrylate adhesive ( $5.5 \mathrm{kN}$ on average).

- Two component toughened methacrylate adhesive can be used for adhesively bonded aluminum sheets of the core applied in composite beams. 
- The load-bearing capacity of joints made with two-component methacrylate adhesive is influenced by the method of applying the glue and the operator's experience.

- The shear resistance of the joints formed by acrylic foam tapes is similar, therefore it does not depend on the type of analysed tapes nor their thickness.

- The joints made with two-component methacrylate adhesive are brittle connections. The joints made with acrylic tapes are characterized by ductile failure.

- Based on the displacement values it was concluded that the joints marked 1 - 3 (bonded by tapes) are ductile connections. On the other hand, the displacement of joint 4 shows that the glued joint is characterized by brittle failure.

\section{References}

[1] Mazzolani F.M., Structural Applications of Aluminium in Civil Engineering, Structural Engineering International 2006, 16 (4), 280-285. doi: 10.2749/101686606778995128.

[2] Matteis G. de, Landolfo R., Manganiello M., Mazzolani F. M., Inelastic behaviour of I-shaped aluminium beams: numerical analysis and cross-sectional classification, Computers \& Structures 2004, 82 (23-26), 2157-2171. doi: 10.1016/j.compstruc.2004.03.071.

[3] Montuori R., Nastri E., Piluso V., Pisapia A., Ultimate behaviour of high-yielding low-hardening aluminium alloy I-beams, Thin-Walled Structures 2020, 146, 1-14. doi: 10.1016/j.tws.2019.106463.

[4] Wang Y. Q., Yuan H. X., Shi Y. J., Cheng M., Lateral-torsional buckling resistance of aluminium I-beams, Thin-Walled Structures 2012, 50(1), 24-36. doi: 10.1016/j.tws.2011.07.005.

[5] Yuan L., Zhang Q., Luo X., Ouyang Y., Yin J., Shear resistance of aluminum alloy extruded H-Section beams, Thin-Walled Structures 2020, 107219. doi: 10.1016/j.tws.2020.107219.

[6] Mazzolani F. M., Competing issues for aluminium alloys in structural engineering, Prog. Struct. Engng Mater. 2004, 6(4), 185-196. doi: 10.1002/pse.178.

[7] Lacki P., Więckowski W., Luty G., Wieczorek P., Motyka M., Evaluation of usefulness of AlCrN coatings for increased life of tools used in friction stir welding (FSW) of sheet aluminum alloy, Materials (Basel, Switzerland) 2020, 13(18), 1-11. doi: 10.3390/ma13184124.

[8] Wieckowski W., Wieczorek P., Lacki J., Investigations of anti-wear coatings in terms of their applicability to tools in the FSW process, Acta Phys. Pol. A 2019, 135(2), 177-182. doi: 10.12693/APhysPolA.135.177.

[9] Larsen B., Hunt J., Hovanski Y., Investigating steel tool life in the RFSSW process, Journal of Manufacturing Processes 2020, 58, 637-645. doi: 10.1016/j.jmapro.2020.07.034.

[10] Adamus J., Pomada M., Selected issues of choosing composite materials for window supporting beams, Journal of Building Engineering 2020, 32, 1-10. doi: 10.1016/j.jobe.2020.101542.

[11] Lacki P., Derlatka A., Strength evaluation of beam made of the aluminum 6061-T6 and titanium grade 5 alloys sheets joined by RFSSW and RSW, Composite Structures 2017, 159, 491-497. doi: 10.1016/j.compstruct.2016. 10.003.

[12] Lacki P., Derlatka A., Influence of PU foam reinforcement of I-beam on buckling resistance, Composite Structures 2018, 202, 201-209. doi: 10.1016/j.compstruct.2018.01.050.

[13] Lacki P., Derlatka A., Winowiecka J., Analysis of the composite I-beam reinforced with PU foam with the addition of chopped glass fiber, Composite Structures 2019, 218, 60-70. doi: 10.1016/j.compstruct.2019.03.036.

[14] Amatya I., Seo J., Jeong E., Lee J., Numerical study for structural performance evaluation of adhesively bonded aluminum dynamic message signs, Thin-Walled Structures 2020, 1-11. doi: 10.1016/j.tws.2020.107193.

[15] Ha D.-W., Jeon G.-W., Shin J.-S., Jeong C.-Y., Mechanical properties of steel-aluminum multi-materials using a structural adhesive, Materials Today Communications 2020, 25, 1-10. doi: 10.1016/j.mtcomm.2020.101552.

[16] You M., Yan Z.-M., Zheng X.-L., Yu H.-Z., Li Z., A numerical and experimental study of gap length on adhesively bonded aluminum double-lap joint, International Journal of Adhesion and Adhesives 2007, 27(8), 696-702. doi: 10.1016/j.ijadhadh.2007.02.005

[17] Kahraman R., Sunar M., Yilbas B., Influence of adhesive thickness and filler content on the mechanical performance of aluminum single-lap joints bonded with aluminum powder filled epoxy adhesive, Journal of Materials Processing Technology 2008, 205 (1-3), 183-189. doi: 10.1016/j.jmatprotec.2007.11.121.

[18] Sadowski T., Golewski P., Zarzeka-Raczkowska E., Damage and failure processes of hybrid joints: Adhesive bonded aluminium plates reinforced by rivets, Computational Materials Science 2011, 50(4), 1256-1262. doi: 10.1016/j.commatsci.2010.06.022.

[19] Lunder O., Olsen B., Nisancioglu K., Pre-treatment of AA6060 aluminium alloy for adhesive bonding, International Journal of Adhesion and Adhesives 2002, 22(2), 143-150. doi: 10.1016/S0143-7496(01)00049-5. 
[20] Correia S., Anes V., Reis L., Effect of surface treatment on adhesively bonded aluminium-aluminium joints regarding aeronautical structures, Engineering Failure Analysis 2018, 84, 34-45. doi: 10.1016/j.engfailanal. 2017.10.010.

[21] Shahzad M.F., Mughal M.P., Iqbal H., Mufti N.A., Saleem M.Q., Polybenzimidazole adhesive bonded aluminum2024 joints for structural applications, International Journal of Adhesion and Adhesives 2019, 95, 102433. doi: 10.1016/j.ijadhadh.2019.102433.

[22] Park S.Y., Choi W.J., Yoon B.C., Analysis of effects of process factors on corrosion resistance of adhesive bonded joints for aluminum alloys, Journal of Materials Processing Technology 2020, 276, 116412. doi: 10.1016/ j.jmatprotec.2019.116412.

[23] Wang M., Liu A., Liu Z., Wang P.-C., Effect of hot humid environmental exposure on fatigue crack growth of adhesive-bonded aluminum A356 joints, International Journal of Adhesion and Adhesives 2013, 40, 1-10. doi: 10.1016/j.ijadhadh.2012.08.008.

\section{Ocena adhezyjnych połączeń blach aluminiowych do aplikacji jako trzon belek kompozytowych}

\section{STRESZCZENIE:}

Dokonano oceny połączeń aluminiowych blach w wyniku adhezji. Celem pracy była ocena możliwości zastosowania tego typu połączeń do budowy belek kompozytowych. Zaprezentowano wyniki badań eksperymentalnych z próby ścinania złączy. Przedmiotem badań były cztery rodzaje złączy. Złącza o identycznej geometrii zbudowano z czterech blach ze stopu aluminium AA 7075-T6 o grubości $1.6 \mathrm{~mm}$. Każdy typ złącza charakteryzował się innym materiałem łączącym blachy: trzy z nich połączono za pomocą akrylowych taśm piankowych, jedno złącze powstało z wykorzystaniem dwuskładnikowego, utwardzanego metakrylowego kleju. Przebadano trzy różne dwustronnie klejące akrylowe taśmy piankowe różniące się właściwościami. Oceniono, iż do budowy konstrukcji kompozytowych opartych na bazie trzonu aluminiowego istnieje możliwość zastosowania dwuskładnikowego, utwardzanego metakrylowego kleju.

SŁOWA KLUCZOWE:

stop aluminum; połączenia adhezyjne; konstrukcje kompozytowe 